\section{Serum IgA in Diabetes}

Dear Sir,

In the August 1982 issue of Diabetologia, Johnston et al. [1] produced arguments in favour of an increased frequency of IgA deficiency in Type 1 (insulin-dependent) diabetes and suggested that low levels of serum IgA are an inherited risk factor for Type 1 diabetic patients. They thus appear to lend support to an earlier finding referring to IgA in juvenile diabetes [2]. In the same issue, Triolo et al. discussed the possible role of IgA-containing circulating immune complexes in the pathogenesis of late complications of diabetes [3].

The situation of IgA in diabetic patients has, we believe, many aspects that are worth discussing. During the period 1979-1982, we determined the principal serum $\operatorname{Ig}(G, A, M)$ values in different groups of diabetic patients (almost 600 cases) both in hospital and under ambulatory conditions. Part of the results are given in Table 1 . The tests were carried out in two different laboratories: groups 1 and 2 in the Clinic of Nutrition and Metabolic Diseases and group 3 in the V. Babeş Institute, Bucharest. A similar method was applied: Mancini radial immunodiffusion, using antisera prepared in the Cantacuzino Institute, Bucharest [4-7].

Mean IgA values higher than mean IgG and IgM values were constantly observed in all these studies. On the other hand, comparative determination of IgA mean values in diabetic patients and healthy control subjects showed significant statistical differences: group $1: 154 \pm 60$ versus $100 \pm 59 \mathrm{IU}$ and group $2: 142 \pm 57$ versus $105 \pm$ $38 \mathrm{IU}(p<0.01)$. These figures refer to the total number of patients in each group.

It is of interest to note that the difference between $\operatorname{IgA}$ and the other classes persisted, irrespective of the clinical features analysed type of diabetes, sex, duration of the disease, age at onset, degree of stability, acute and chronic complications, etc. This was observed even in cases of ketoacidosis. Nevertheless, in the latter more numerous group, the highest serum IgA values were found in elderly diabetic patients (onset after the age of 65 years: $204 \pm 85 \mathrm{IU}$ ) and those with renal complications ( $204 \pm 56$ IU).

The explanation of this phenomenon is not very clear. However, if an error is excluded, one might take into consideration the structural and metabolic particularities of IgA under the specific conditions of diabetes. Close, parallel examination of the metabolic properties of the three principal immunoglobulins reveals the higher daily catabolic rate of $\operatorname{IgA}(25 \%)[8,9]$. This suggests that the increase in serum $\operatorname{IgA}$ in diabetic patients is correlated with its changed catabolism rather than with changes in other metabolic sequences.

Yours sincerely,

D. Cheța

\section{References}

1. Johnston C, Vergani D, Binabdullah N (1982) IgA deficiency in Type 1 (insulin-dependent) diabetes - an inherted association. Diabetologia 23: 177-178

2. Smith VI Jr, Rabin BS, Huellmantel A, Van Thiel D, Drash A (1978) Immunopathology of juvenile onset diabetes mellitus. I. IgA deficiency and juvenile diabetes. Diabetes 27: 1092-1097

3. Triolo G, Giardina E, Rinaldi A, Bompiani GD (1982) IgA-containing circulating immune complexes in diabetes mellitus. Diabetologia 23: 206 (Abstract)

4. Mihalache N, Cheța D, Ionescu-Tîrgovişte C, Popescu E, Ionescu C (1979) Studiu immunologic asupra cineticii unor fracţiuni proteice în cetoacidoza diabetică. Viața medicală $26: 71-73$

5. Cheța $D$, Lenkei R, Mihăescu S, Mihalache N, Ionescu-Tîrgoviște C, Popescu C (1979). Immunological study of liver diseases in diabetics. Rev Roum Méd - Méd Int 17: 59-66

6. Cheţa D, Mihalache N, Sântu E, Mincu I (1980) Study of some blood protein fractions in various forms of diabetes mellitus. Diabetologia 19: 264 (Abstract)

7. Cheța D, Mihăescu S, Mihalache N (1982) Immunoglobulin A in diabetics. Rev Roum Méd - Méd Int 20: 15-17

8. Kehoe JM (1978) The structural basis for the biological properties of immunoglobulins. In: Litman GW, Good RA (eds) Immunoglobulins. Plenum Medical Books, New York, London, pp 173-198

9. Păunescu E (1981) Immunoglobulinele. In: Berceanu S, Păunescu E (eds) Biologia și patologia immunităţii. Ed Acad RSR, Bucureşti, pp 64-90

\section{Dr. D. Cheța}

Clinic of Nutrition and Metabolic Diseases,

5 , Ion Movilă Street

70266 Bucharest 2

Roumania

Table 1. Serum immunoglobulin values in three different groups of diabetic patients

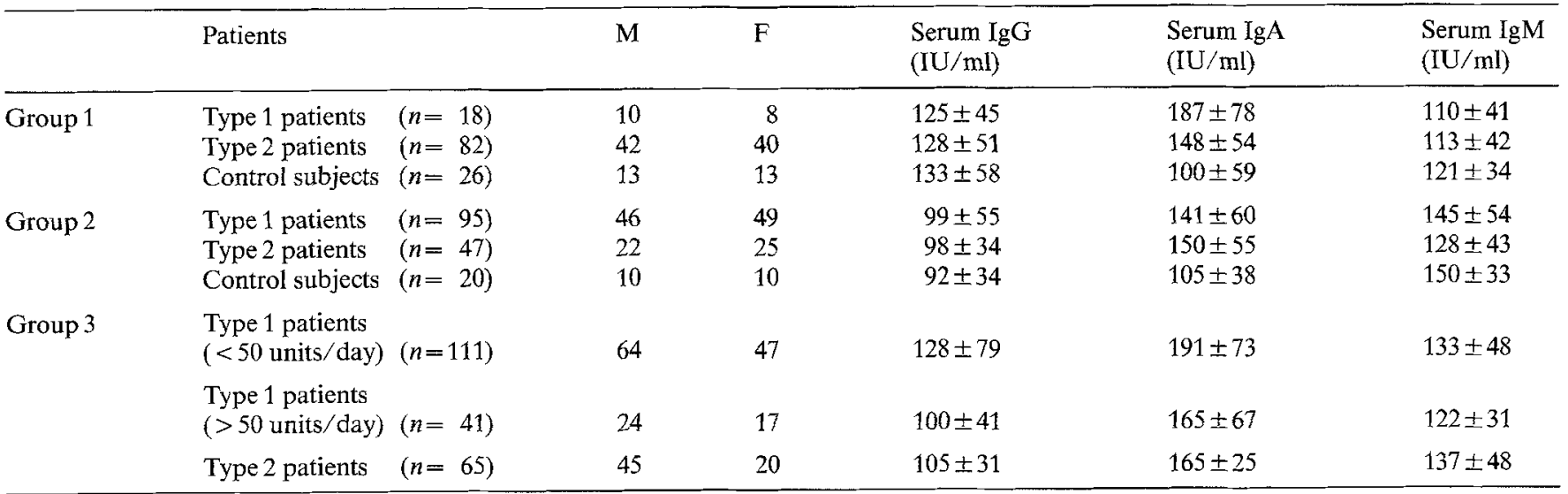

Results expressed as mean $\pm \mathrm{SD}$ 